\section{Hygiene assessment of essix retainers via a patient questionnaire}

\section{Essix retansiyon apareylerinin hasta anketleri ile hijyen değerlendirmesi}

\author{
Assist. Prof. Delal Dara Kılınç \\ Istanbul Medipol University, Faculty of Dentistry, \\ Department of Orthodontics, Istanbul, Turkey \\ Orcid ID: 0000-0001-9009-6218
}

\section{Assist. Prof. Gülșilay Sayar}

Istanbul Medipol University, Faculty of Dentistry, Department of Orthodontics, Istanbul, Turkey

Orcid ID: 0000-0003-3294-2644

Received: 7 September 2017

Accepted: 12 February 2018

doi: 10.5505/yeditepe.2019.86580

\section{Corresponding author:}

Assist. Prof.Delal Dara KILINÇ

Istanbul Medipol University, School of Dentistry,

Department of Orthodontics. Atatürk Bulvarı No: 27.

34083, Unkapanı -Fatih /Istanbul, Turkey

Phone: +90 50645997 71, +90 2124534952

\section{SUMMARY}

Aim: The aim of this study was to investigate the hygiene habits and cleaning methods of patients who are wearing Essix plates for retention, by a face to face applied questionnaire.

Material and Methods: 120 patients (72 females, 48 males) using Essix Plates in post-treatment retention period were enrolled for this study. Subjects were aged $18-40$ years. All of the subjects were conducted a questionnaire by the same experienced clinician. The questionnaire investigated the genders of subjects, ages of subjects, and methods and frequency of cleaning plates.

Results: Half of the subjects clean their plates whenever they remove it. There is a difference between median ages according to the frequency of clearing the plates $(p<0.001)$. There is no difference between the ages about; how the plates are cleaned, what they use to clean, the difficulty in cleaning, and the belief about the plates are clean enough ( $p$ values are $0.833,0.178,0.120$ and 0.251 , respectively). The belief that plates are sufficiently clean does not differ according to sex $(p=0.871$ ). According to age distribution, there was a statistically significant correlation the frequency of clearing the age groups and plates, the way of clearing the plates, the agent to be used to clean the plates and the belief of cleanliness of the plates $(\mathrm{p}<0.05)$.

Conclusions: There is not a common method of cleaning the Essix plates amongst patients. Patients refer various materials to clean their Essix plates. The frequencies of cleaning their plates also differ amongst patients. Various hygiene habits were present in different age groups.

Keywords: Orthodontic Retainer, Essix Plates, Hygiene, Disinfection.

\section{ÖZET}

Amaç: Bu çalışmanın amacı ortodontik tedavi sonrası retansiyon döneminde Essix plak taşıyan hastaların hijyen alışkanlıklarının anketler aracılığı ile değerlendirilmesidir.

Gereç ve Yöntem: Çalışmaya ortodontik tedavisi bitmiş ve retansiyon amacı ile Essix plak kullanan, 18-40 yaş aralığındaki 120 hasta (72 kadın, 48 erkek) dahil edilmiştir. Hastaların hepsine klinik tecrübesi olan aynı ortodontist tarafından anketler uygulanmıştır. Anket hastaların yaşlarını, cinsiyetlerini, hastaların plakları temizleme metodlarını ve sıklıklarını incelemiştir. Bulgular: Hastaların yarısı, plaklarını her çıkardıkarında temizlediklerini belirtmiştir. Plakları temizleme sıklı̆ına göre hastaların ortalama yaşı arasında farklıık bulunmaktadır $(p<0,001)$. Plakların nasıl temizlendiği, temizlemek için kullanılan ajan, temizlemede güçlük, plakların temizliği konusundaki görüş açısından ortalama yaşta farklıık yoktur ( $p$ değerleri sırasıyla $0,833,0,178,0,120$ ve 0,25 ). Plakların temizliği ile ilgili düşünce cinsiyetten bağımsızdır ( $p=, 871)$. Yaş dağıımına göre plakların temizleme sıklığı, nasıl temizlendiği, kullanılan temizleme ajanı temizlik hakkında görüş arasında istatistiksel olarak anlamlı farklılık bulunmaktadır ( $p<0,05)$. 
Sonuç: Hastalar arasında Essix plaklarının temizlenmesi açısından çeşitlilik olduğu, hastaların plaklarını temizlemek için farklı materyaller tercih ettiği anlaşılmıştır.

Anahtar kelimeler: Ortodontik Pekiştirme Apareyleri, Essix Plaklar, Hijyen, Dezenfeksiyon.

\section{INTRODUCTION}

The accurate instructions for disinfection of removable orthodontic appliances is still not defined clearly in the literature.

Oral environment adapts to the presence of orthodontic appliances by increasing the stimulated flow rate, buffer capacity and salivary $\mathrm{PH}$ to increase the anti-cariogenic potential of saliva. ${ }^{2}$ In contrary to a study which reported an insignificant change in the amount of the microorganisms in oral microflora by use of orthodontic appliances ${ }^{3}$ some other studies reported that orthodontic appliances may change the oral microbiota and increase the concentration of mutans streptococci (MS) and lactobacilli in saliva and dental biofilm which can lead to dental caries and periodontal diseases. ${ }^{1,4-5}$ Bacterial colonization occurs on the removable appliance as a biofilm. ${ }^{1}$ In previous studies it was presented that a removable appliances were contaminated with microorganisms just after 1 week of wearing. ${ }^{1,6}$ Candidal carriage risqué of removable appliances was also reported in some earlier studies. ${ }^{7-9}$

Essix plates, removable vacuum formed thermoplastic retention appliances were first presented to the orthodontic literature by J. Jack Sheridan in 1993.10 Essix plates are frequently preferred removable retention appliances in contemporary orthodontic practice. ${ }^{11-14}$

As being generally a full time worn retention appliance, the hygiene of the Essix plates are also so effective on oral microbiata. In the literature, there could not be found a study which is directly focused on the disinfection methods of Essix plates. This study aimed to evaluate the hygiene habits and attitudes of Essix plate wearing patients in the post-treatment retention period via a questionnaire.

\section{MATERIALS AND METHOD}

Ethical committee's approval of this study was given by research Ethics Committee with protocol number: 10840098-604.01.01-E.25322.

The power of the study was calculated using $G *$ Power software (G*Power Ver. 3.0.10., Kiel, Germany) and was found that with 100 patients would give $80 \%$ power with a $95 \%$ confidence interval (Cl).

120 patients (72 Females and 48 males) which were in post-treatment retention period and were wearing Essix plates for retention, were enrolled in this study. The selection criteria for this study were; patients over age of 18 , having no systemic disease, with similar demographic characteristics, having no disabilities to clean their plates, having no caries, had periodontology consultation for oral hygiene and having no periodontal problems. Subjects were aged from 18 to 40 years. The mean age of the patients was $29.2 \pm 6.4$ year.

All of the subjects were conducted a questionnaire by the same experienced clinician. A pilot testing was managed before the study, ${ }^{12}$ patients were asked the questions and validation managed. Reliability and internal consistency value (Cronbach alfa) was 0,84 .

The questionnaire examined the genders of subjects, ages of subjects, and methods and frequency of cleaning plates. The questions of the questionnaire were prepared by two researchers of this study who are both 10 years experienced clinicians in orthodontics.

Questionnaire;

1. How often do you clean your plates?

2. How do you clean your plates?

3. What materials do you use for cleaning?

4. Is it difficult for you to clean your plates? (A. Yes, B. No)

5. Do you think that your plate is hygienic? (A. Yes, B. No) Statistical analysis

The data was analyzed with IBM SPSS V23. Mann Whitney $\mathrm{U}$ test and Chi-square test were used to compare the data. Quantitative data were presented as mean, standard deviation, median, min, max, while qualitative data were presented as frequency and percentage. Significance level was taken as $\mathrm{p}<0.05$.

\section{RESULTS}

In a total of 120 people surveyed, $40 \%$ of the participants were male while $60 \%$ were female. The rate of clearing the plates once a day is $10 \%$, while the rate of clearing twice a day is $40 \%$ and the rate of cleaning whenever he/she removes is $50 \%$. The rate of cleaning the plates by brushing under running water is $10 \%$, while the rate of cleaning with running tap water only is $90 \%$. The proportion of users using toothpaste to clean the plates is $50.8 \%$, the proportion of soap users is $12.5 \%$, the proportion of users using only water is $33.3 \%$, and the rate of users using cleaning tablets is $3.3 \%$. The percentage of those who stated that they had difficulties while clearing the plates was $5.8 \%$ and $70 \%$ of the participants believed that the plates were clean enough (Table 1). 
Table 1. Frequency and percentage of the answers.

\begin{tabular}{|c|c|c|}
\hline & Frequency & $\%$ \\
\hline \multicolumn{3}{|l|}{ Gender } \\
\hline Male & 48 & 40 \\
\hline Female & 72 & 60 \\
\hline \multicolumn{3}{|l|}{ How often do you clean your plates? } \\
\hline Once a day & 12 & 10 \\
\hline Twice a day & 48 & 40 \\
\hline Whenever i remove & 60 & 50 \\
\hline \multicolumn{3}{|l|}{ How do you clean your plates? } \\
\hline Brushing under water & 12 & 10 \\
\hline Only with tap water & 108 & 90 \\
\hline \multicolumn{3}{|c|}{ What materials do you use for cleaning? } \\
\hline Toothpaste & 61 & 50.8 \\
\hline Soap & 15 & 12.5 \\
\hline Only water & 40 & 33.3 \\
\hline Cleansing tablets & 4 & 3.3 \\
\hline \multicolumn{3}{|c|}{ Is it difficult for you to clean your plates? } \\
\hline Yes & 7 & 5.8 \\
\hline No & 113 & 94.2 \\
\hline \multicolumn{3}{|c|}{ Do you think that your plate is hygienic? } \\
\hline Yes & 84 & 70 \\
\hline No & 36 & 30 \\
\hline
\end{tabular}

There is a difference between median ages according to the frequency of clearing the plates $(p<0.001)$. The median age of the cleansers once a day was 23 , the number of cleansers twice a day was 32 , and the median age of the cleansers whenever removes was 28 . There is a difference in the age of all cleaning cycles. There is no difference between the ages about; how the plates are cleaned, what they use to clean, the difficulty in cleaning, and the belief about the plates are clean enough ( $p$ values are $0.833,0.178,0.120$ and 0.251 , respectively). The results were shown in Table 2.

Table 2. Median (min-mak), a-c: There is no difference between groups with the same letter.

\begin{tabular}{|c|c|c|}
\hline & Age & $\mathbf{p}$ \\
\hline \multicolumn{3}{|l|}{ How often do you clean your plates? } \\
\hline Once a day & $23(18-29) \mathrm{a}$ & \multirow[t]{3}{*}{$<0.001$} \\
\hline Twice a day & $32(21-40) b$ & \\
\hline Whenever i remove & $28(18-40) c$ & \\
\hline \multicolumn{3}{|l|}{ How do you clean your plates? } \\
\hline Brushing under water & $26(23-40)$ & \multirow[t]{2}{*}{0.833} \\
\hline Only with tap water & $29(18-40)$ & \\
\hline \multicolumn{3}{|c|}{ What materials do you use to clean your plates? } \\
\hline Toothpaste & $28(18-40)$ & \multirow[t]{4}{*}{0.178} \\
\hline Soap & $27(20-40)$ & \\
\hline Only water & $32(18-40)$ & \\
\hline Cleansing tablets & $37,5(21-40)$ & \\
\hline \multicolumn{3}{|c|}{ Do you think that it is difficult to clean your plates? } \\
\hline Yes & $33(26-39)$ & \multirow[t]{2}{*}{0.120} \\
\hline No & $29(18-40)$ & \\
\hline \multicolumn{3}{|c|}{ Do you think that your plates are cleaned enough? } \\
\hline Yes & $28(18-40)$ & \multirow[t]{2}{*}{0.251} \\
\hline No & $31(18-40)$ & \\
\hline
\end{tabular}

The belief that plates are sufficiently clean does not differ according to sex $(p=0.871) .69 .4 \%$ of females and $70.8 \%$ of males believe that they are adequately cleaned. The belief that plates are sufficiently clean does not depend on the frequency of plate clearance and difficulty in clearing ( $p$ values of 0.147 and 0.350 , respectively). The belief that plate is clean enough depends on how the plates are cleaned $(p=0.017)$. Whilst all of the flushers under the flowing water believe that the plates are clean enough, only $66.7 \%$ of flushers believe in it. Likewise, the belief that plates are clean enough depends on the material used for cleaning $(p=0.035)$. They believe that $82 \%$ of toothpaste users, $60 \%$ of soap users, $57.5 \%$ of water users and $50 \%$ of users of cleaning tablets are clean enough. These results were shown in Table 3.

Table 3. The relation of the thought of the cleanliness of plates with the other variables.

\begin{tabular}{|c|c|c|c|}
\hline & \multicolumn{2}{|c|}{$\begin{array}{c}\text { Do you think that your plate is } \\
\text { hygienic? }\end{array}$} & \\
\hline & Yes & No & \\
\hline \multicolumn{4}{|l|}{ Gender } \\
\hline Male & $34(70,8)$ & $14(29,2)$ & \multirow[t]{2}{*}{0.871} \\
\hline Female & $50(69,4)$ & $22(30,6)$ & \\
\hline \multicolumn{4}{|l|}{ How often do you clean your plates? } \\
\hline Once a day & $10(83,3)$ & $2(16,7)$ & \multirow[t]{3}{*}{0.147} \\
\hline Twice a day & $29(60,4)$ & $19(39,6)$ & \\
\hline Whenever i remove & $45(75)$ & $15(25)$ & \\
\hline \multicolumn{4}{|l|}{ How do you clean your plates? } \\
\hline Brushing under water & $12(100)$ & --- & \multirow[t]{2}{*}{0.017} \\
\hline Only with tap water & $72(66,7)$ & $36(33,3)$ & \\
\hline \multicolumn{4}{|c|}{$\begin{array}{l}\text { What materials do you use to clean your } \\
\text { plates? }\end{array}$} \\
\hline Toothpaste & $50(82)$ & $11(18)$ & \multirow[t]{4}{*}{0.035} \\
\hline Soap & $9(60)$ & $6(40)$ & \\
\hline Only water & $23(57,5)$ & $17(42,5)$ & \\
\hline Cleansing tablets & $2(50)$ & $2(50)$ & \\
\hline \multicolumn{4}{|c|}{ Is it difficult for you to clean your plates? } \\
\hline Yes & $6(85,7)$ & $1(14,3)$ & \multirow[t]{2}{*}{0.350} \\
\hline No & $78(69)$ & $35(31)$ & \\
\hline
\end{tabular}

The frequency of clearing the plates depends on the sex $(p=0.001) .33 .3 \%$ of women clean up twice a day and $62.5 \%$ clean up every time they remove, while $50 \%$ of men clean twice a day and $31.3 \%$ every time they remove. It is not sex-dependent: the method of cleaning the plates, to believe that the plates are cleaned, difficulties to clean, and the material used to clean. (Table 4) 
Table 4. Frequency (Percentage) Distribution of parameters according to gender.

\begin{tabular}{|c|c|c|c|}
\hline & \multicolumn{2}{|c|}{ Gender } & \\
\hline & Male & Female & \\
\hline \multicolumn{4}{|l|}{ How often do you clean your plates? } \\
\hline Once a day & $9(18.8)$ & $3(4.2)$ & \multirow[t]{3}{*}{0.001} \\
\hline Twice a day & $24(50)$ & $24(33.3)$ & \\
\hline Whenever i remove & $15(31.3)$ & $45(62.5)$ & \\
\hline \multicolumn{4}{|l|}{ How do you clean your plates? } \\
\hline Brushing under water & $5(10.4)$ & $7(9.7)$ & \multirow[t]{2}{*}{0.901} \\
\hline Only with tap water & $43(89.6)$ & $65(90.3)$ & \\
\hline \multicolumn{4}{|c|}{ What materials do you use to clean your plates? } \\
\hline Toothpaste & $29(60.4)$ & $32(44.4)$ & \multirow[t]{4}{*}{0.341} \\
\hline Soap & $4(8.3)$ & $11(15.3)$ & \\
\hline Only water & $14(29.2)$ & $26(36.1)$ & \\
\hline Cleansing tablets & $1(2.1)$ & $3(4.2)$ & \\
\hline \multicolumn{4}{|c|}{ Is it difficult for you to clean your plates? } \\
\hline Yes & $3(6.3)$ & $4(5.6)$ & \multirow[t]{2}{*}{0.874} \\
\hline No & $45(93.8)$ & $68(94.4)$ & \\
\hline \multicolumn{4}{|c|}{ Do you think that your plate is hygienic? } \\
\hline Yes & $34(70.8)$ & $50(69.4)$ & \multirow[t]{2}{*}{0.871} \\
\hline No & $14(29.2)$ & $22(30.6)$ & \\
\hline
\end{tabular}

The results of the chi-square analysis applied to test the relationship between age groups and the provision of hygiene were shown in Table 5.

Table 5. Chi-square test results.

\begin{tabular}{ll}
\hline Variable & Significance \\
\hline Gender & 0.466 \\
How often do you clean your plates? & 0.016 \\
How do you clean your plates? & 0.001 \\
What materials do you use to clean your plates? & $<0.001$ \\
Do you think that it is difficult to clean your plates? & 0.693 \\
Do you think that your plates are cleaned enough? & 0.027 \\
\hline
\end{tabular}

There was a statistically significant correlation between the statistical significance of the test statistics and the frequency of clearing the age groups and plates, the way of clearing the plates, the instrument to be used to clean the plates and the cleanliness of the plates $(p<0.05)$. Statistically significant variables were interpreted by adding cross tables.

Table 6 shows the frequency of clearing the plates and the cross table for the age groups. According to this table, $73 \%$ of individuals between the ages of $18-25$ are clean their plates whenever they remove, $50 \%$ of individuals aged 26-33 are clean their plates twice a day, and $48.6 \%$ of individuals between the ages of 34-41 clean their plates once a day.
Table 6. Cross-table of age groups with frequency of clearing plates.

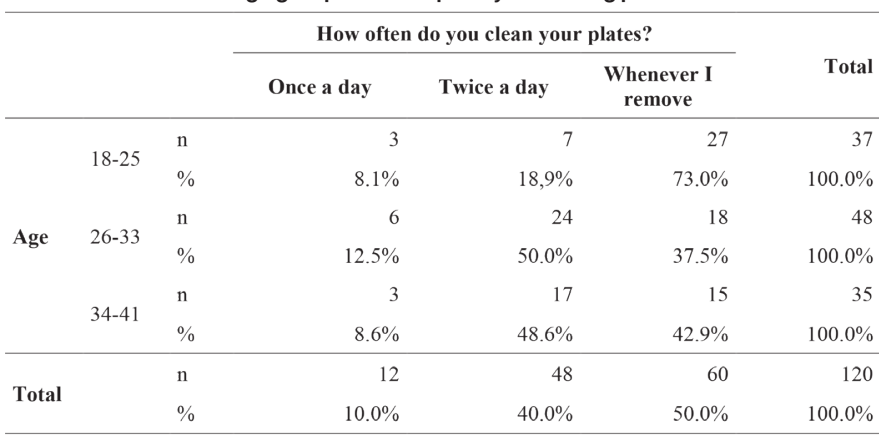

Table 7 shows a cross-table of age groups in the form of clearing the plates. According to this table, $97.3 \%$ of individuals between the ages of $18-25,95.8 \%$ of the individuals between the ages of $26-33$ and $74.3 \%$ of the individuals between the ages of 34-41 clean the plates only with tap water.

\begin{tabular}{|c|c|c|c|c|c|}
\hline & & & \multicolumn{2}{|c|}{ How do you clean your plates? } & \multirow[b]{2}{*}{ Total } \\
\hline & & & $\begin{array}{l}\text { Brushing under } \\
\text { water }\end{array}$ & Only with tap water & \\
\hline \multirow{6}{*}{ Age } & \multirow{2}{*}{$18-25$} & $\mathrm{n}$ & 1 & 36 & 37 \\
\hline & & $\%$ & $2.7 \%$ & $97.3 \%$ & $100.0 \%$ \\
\hline & \multirow{2}{*}{$26-33$} & $\mathrm{n}$ & 2 & 46 & 48 \\
\hline & & $\%$ & $4.2 \%$ & $95.8 \%$ & $100.0 \%$ \\
\hline & \multirow{2}{*}{$34-41$} & $\mathrm{n}$ & 9 & 26 & 35 \\
\hline & & $\%$ & $25.7 \%$ & $74.3 \%$ & $100.0 \%$ \\
\hline \multirow{2}{*}{ Total } & & $\mathrm{n}$ & 12 & 108 & 120 \\
\hline & & $\%$ & $10.0 \%$ & $90.0 \%$ & $100.0 \%$ \\
\hline
\end{tabular}

Table 8 shows a cross-table of age groups with the cleaning materials of the plates. According to this table, $78.4 \%$ of individuals aged 18-25 years clean their plates with toothpaste, $52.1 \%$ of individuals aged $26-33$ clean only with tap water and $54.3 \%$ of individuals aged $34-41$ clean their plates with toothpaste.

Table 8. Cross-table of age groups with plates cleansing agent.

\begin{tabular}{|c|c|c|c|c|c|c|c|}
\hline & & & \multicolumn{4}{|c|}{ What materials do you use to clean your plates? } & \multirow[b]{2}{*}{ Total } \\
\hline & & & Toothpaste & Soap & Only Water & $\begin{array}{c}\text { Cleansing } \\
\text { Tablets }\end{array}$ & \\
\hline \multirow{6}{*}{ Age } & \multirow{2}{*}{$18-25$} & $\mathrm{n}$ & 29 & 3 & 5 & 0 & 37 \\
\hline & & $\%$ & $78.4 \%$ & $8.1 \%$ & $13.5 \%$ & $0.0 \%$ & $100.0 \%$ \\
\hline & \multirow{2}{*}{$26-33$} & $\mathrm{n}$ & 13 & 8 & 25 & 2 & 48 \\
\hline & & $\%$ & $27.1 \%$ & $16.7 \%$ & $52.1 \%$ & $4.2 \%$ & $100.0 \%$ \\
\hline & \multirow{2}{*}{$34-41$} & $\mathrm{n}$ & 19 & 4 & 10 & 2 & 35 \\
\hline & & $\%$ & $54.3 \%$ & $11.4 \%$ & $28.6 \%$ & $5.7 \%$ & $100.0 \%$ \\
\hline \multirow{2}{*}{ Total } & & $\mathrm{n}$ & 61 & 15 & 40 & 4 & 120 \\
\hline & & $\%$ & $50.8 \%$ & $12.5 \%$ & $33.3 \%$ & $3.3 \%$ & $100.0 \%$ \\
\hline
\end{tabular}

Table 9 shows the views of the cleanliness of the plates and the cross table for the age groups. According to this table, $70.3 \%$ of the individuals between the ages of $18-25$, $58.3 \%$ of the individuals between the ages of $26-33$ and $85.7 \%$ of the individuals between the ages of $34-41$ think that the plates can be cleaned enough. 
Table 9. Cross-table of views of cleanliness and age groups.

\begin{tabular}{|c|c|c|c|c|c|}
\hline & & & \multicolumn{2}{|c|}{$\begin{array}{l}\text { Do you think that your plates are } \\
\text { cleaned enough? }\end{array}$} & \multirow{2}{*}{ Tota } \\
\hline & & & Yes & No & \\
\hline \multirow{6}{*}{ Age } & \multirow{2}{*}{$18-25$} & $\mathrm{n}$ & 26 & 11 & 37 \\
\hline & & $\%$ & $70.3 \%$ & $29.7 \%$ & $100.0 \%$ \\
\hline & \multirow{2}{*}{$26-33$} & $\mathrm{n}$ & 28 & 20 & 48 \\
\hline & & $\%$ & $58.3 \%$ & $41.7 \%$ & $100.0 \%$ \\
\hline & \multirow{2}{*}{$34-41$} & $\mathrm{n}$ & 30 & 5 & 35 \\
\hline & & $\%$ & $85.7 \%$ & $14.3 \%$ & $100.0 \%$ \\
\hline \multirow{2}{*}{ Total } & & $\mathrm{n}$ & 84 & 36 & 120 \\
\hline & & $\%$ & $70.0 \%$ & $30.0 \%$ & $100.0 \%$ \\
\hline
\end{tabular}

\section{DISCUSSION}

Essix plates are one of the most preferred removable orthodontic retention appliances in daily orthodontic practice. Nevertheless, we could not find a study focusing directly on the hygiene habits and methods of Essix plate wearing patients in the literature.

Bacterial and fungal concentration in oral microflora may increase by fixed or removable orthodontic appliances. ${ }^{5,7,9}$ In a previous study, it was stated that there was not a way of disinfecting the removable appliances absolutely but it could be possible to disinfect them the most, in some ways. ${ }^{15}$

In the literature, there are studies investigating the mechanical, chemical and combination of both methods for disinfection of removable appliances..$^{16}$ The best method of disinfecting a removable appliance was stated to be ultrasound bath and cleaning with chemicals. ${ }^{15}$

In some previous studies, it was presented that immersing appliances into water with chemical agents for a while for disinfection was usually recommended by the clinicians. ${ }^{17,18}$ However, Lamas et al. ${ }^{16}$ stated that mechanical cleaning was the most preferred way of cleaning appliances amongst the patients and clinicians.

Da Silva et al. ${ }^{19}$, presented in their study that $1 \%$ sodium hypochlorite, $2 \%$ glutaraldehyde, $2 \%$ chlorexidine, $100 \%$ vinegar, and $3.8 \%$ sodium perborate were effective in disinfection of removable dentures. Peixoto et al. ${ }^{6}$, indicated that gold standard for the elimination of biofilm compared to other chemicals was the use of chlorhexidine. Lessa et al., evaluated the effects of two different chemical agents; chlorhexidine gluconate and cetilpyridinium chloridine in the disinfection of removable appliances. Cleaning with both chemical agents were found to be effective in elimination of the microorganisms. Immersing into water with sodium hypochlorite was another practical and economical way of cleaning plates, amongst patients. ${ }^{1}$ Although having an effective and fast antimicrobial activity, sodium hypochlorite can have serious cytotoxic side effects. ${ }^{15,16}$ In previous studies, using toothbrush and toothpaste under tap water was found to be the frequent way of cleaning plates. ${ }^{15,16}$ These results were consistent with our study. In our study, using toothpaste as cleansing material and brushing the plates under tap water was the most preferred way of cleaning: \%51 of our subjects preferred this method to clean their Essix plates. According to age groups; the patients between 18-25 and 34-41 most preferred to use toothpaste. However, this can cause abrasion on the surface of the appliances which can lead to a harmed surface for microbial retention. ' Some of the subjects in this study also stated that brushing with toothpaste harmed the surface smoothness of their plates which lead to a dull surface.

Washing the appliances under running tap water without any cleansing agents is another frequent preferred mechanical way of cleaning appliances in all of the age groups. However, is not found to be effective enough to remove the microorganisms on the retentive areas of the appliances. Hence, it was stated that brushing with a chemical antimicrobial agent could provide a proper appliance hygiene by the elimination of bacterial biofilm. ${ }^{17}$ In this study the method preferred by $\% 10$ of subjects in cleaning their plates was washing the plates under running tap water solely without using any chemical agents or brushes. Nevertheless \%33 of subjects stated that they used only water as a cleansing material without any chemicals.

Soap or cleaning foams were the cleansing materials which were preferred by $\% 13$ of our subjects in cleaning their plates. Soaking into water with cleansing tablets was the lesser preferred way to clean plates. Only \%3 of our subjects stated that they used cleansing tablets. This could be because of the costs of the such cleansing agents.

In present study \%30 of the subjects stated that they did not think that their plates were hygienic. The belief of cleanliness of the plates were highest in elderly age group (34-41). Many of the patients complained about the bad smell of the plates and stated that they wanted to learn a way of deodorization of their Essix plates. Soaking into cleansing tablets periodically was offered to these patients to solve this problem.

In our study, \%94 of the subjects mentioned that it was not difficult for them to clean the plates. Nevertheless, $\% 50$ of subjects said that they cleaned their plates whenever they remove it while $\% 40$ once a day and $\% 10$ twice a day, respectively. It was clinically observed that using these plates, cleaning and taking care of these plates had some difficulties for patients. The youngest group showed the highest frequency of cleaning the plates.

\section{CONCLUSION}

There is not a common method of cleaning the Essix plates amongst patients. Patients refer various materials to clean their Essix plates. The frequencies of cleaning their plates also differ amongst patients. Hygiene habits were also different according to age groups. 


\section{REFERENCES}

1.Lessa FCR, Enoki C, Ito IY, Faria G, Matsumoto, M. A. N., Nelson-Filho, P. In-vivo evaluation of the bacterial contamination and disinfection of acrylic baseplates of removable orthodontic appliances. American Journal of Orthodontics and Dentofacial Orthopedics 2007; 131(6): 705-e11.

2.Lara-Carrillo E, Montiel-Bastida NM, Sánchez-Pérez L, Alanís-Tavira J. Effect of orthodontic treatment on saliva, plaque and the levels of Streptococcus mutans and Lactobacillus. Med Oral Patol Oral Cir Bucal 2010; 15(6): e924-9.

3.Ulukapi $H$, Koray F, Efes B. Monitoring the caries risk of orthodontic patients. Quintessence international 1997; 28(1).

4.Batoni G, Pardini M, Gianotti A, Ota F, et al. Effect of removable orthodontic appliances on oral colonisation by mutans streptococci in children. European journal of oral sciences 2001; 109(6): 388-392.

5.Topaloglu-Ak A, Ertugrul F, Eden, E, Ates M, Bulut H. Effect of orthodontic appliances on oral microbiota. 6-month follow-up. Journal of Clinical Pediatric Dentistry 2011; 35(4): 433-436.

6.Peixoto ITA, Enoki C, Ito IY, Matsumoto MAN, Nelson-Filho P. Evaluation of home disinfection protocols for acrylic baseplates of removable orthodontic appliances: A randomized clinical investigation. American Journal of Orthodontics and Dentofacial Orthopedics 2011; 140(1): 51-57.

7.Addy M, Shaw WC, Hansford P, Hopkins M. The effect of orthodontic appliances on the distribution of Candida and plaque in adolescents. British journal of orthodontics 1982; 9(3): 158-163.

8. Arendorf, T, Addy M. Candidal carriage and plaque distribution before, during and after removable orthodontic appliance therapy. Journal of clinical periodontology 1985; 12(5): 360-368.

9.Hägg, U., Kaveewatcharanont, P., Samaranayake, Y. H., \& Samaranayake, L. P. The effect of fixed orthodontic appliances on the oral carriage of Candida species and Enterobacteriaceae. The European Journal of Orthodontics, 2004; 26(6), 623-629.

10.Sheridan JJ, LeDoux W., \& McMinn, R. Essix retainers: fabrication and supervision for permanent retention. Journal of clinical orthodontics: 1993; 27(1), 37-45.

11.Jäderberg S, Feldmann I, Engström C. Removable thermoplastic appliances as orthodontic retainers-a prospective study of different wear regimens. The European Journal of Orthodontics 2011; 34(4): 475-479.

12.Kumar $A G$, Bansal $A$. Effectiveness and acceptability of Essix and Begg retainers: a prospective study. Australian orthodontic journal 2011; 27(1): 52.

13.Demir A, Babacan H, Nalcacı R, Topcuoglu T. Compa- rison of retention characteristics of Essix and Hawley retainers. The Korean Journal of Orthodontics 2012; 42(5): 255-262.

14.Johnston CD, Littlewood SJ. Retention in orthodontics. British dental journal 2015; 218(3): 119.

15.Eichenauer J, Serbesis $C$, Ruf $S$. Cleaning removable orthodontic appliances-a survey. Journal of Orofacial Orthopedics/Fortschritte der Kieferorthopädie 2011; 72(5): 389.

16.Lamas RRS, Salas MMS, Cenci TP, Corrêa MB, Lund RG. Removable orthodontic appliances: frequency and cleaning agents used by students and recommended by dentists. Brazilian Journal of Oral Sciences 2016; 15(1): 2126.

17.Dills SS, Olshan AM, Goldner S, Brogdon C. Comparison of the antimicrobial capability of an abrasive paste and chemical-soak denture cleaners. The Journal of prosthetic dentistry 1988; 60(4): 467-470.

18. Pavarina AC, Pizzolitto AC, Machado AL, Vergani $C E$, Giampaolo, ET. An infection control protocol: effectiveness of immersion solutions to reduce the microbial growth on dental prostheses. Journal of oral rehabilitation 2003; 30(5): 532-536.

19.Da Silva FC, Kimpara ET, Mancini MN, Balducci I, et al. Effectiveness of six different disinfectants on removing five microbial species and effects on the topographic characteristics of acrylic resin. Journal of Prosthodontics, 2008; 17(8): 627-633. 